Jurnal Konstruksi Hukum | ISSN: XXXX | E-ISSN: XXXX Vol. 1, No. 2, Oktober 2020, Hal. 320-324| Available online at https://www.ejournal.warmadewa.ac.id/index.php/jukonhum DOI: https://doi.org/10.22225/jkh.1.2.2561.320-324

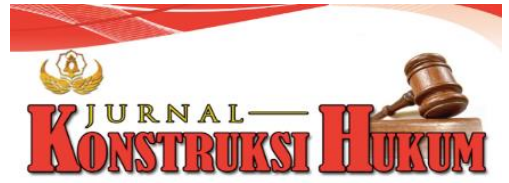

\title{
PENGATURAN JUMLAH MINIMAL MODAL DASAR PADA PENDIRIAN PERSEROAN TERBATAS
}

\author{
I Gusti Ayu Manik Maharani, Desak Gde Dwi Arini, Luh Putu Suryani \\ Fakultas Hukum Universitas Warmadewa, Denpasar-Bali, Indonesia
}

\begin{abstract}
Abstrak
Di dalam Pasal 33 UUPT, mengenai pengaturan modal sebuah PT ditentukan Paling sedikit adalah $25 \%$ dari modal dasar dalam pasal 32 UUPT harus ditempatkan dan disetor penuh. Penelitian ini bertujuan untuk mengetahui pengaturan jumlah minimal modal dasar pada pendirian PT dan mengetahui akibat kedudukan hukum PT yang didirikan dengan jumlah modal dasar yang kurang dari ketentuan dalam UUPT. Penelitian ini menggunakan metode penelitian hukum normatif dengan pendekatan Perundang-Undangan dan konsep Hukum. Hasil penelitian menunjukan bahwa pengaturan modal dasar PT pada PP Nomor 29 Tahun 2019 bertentangan dengan Pasal 32 ayat (1), Mendirikan PT sampai memperoleh badan hukum tidak cukup dengan cara membuat Anggaran Dasar PT saja, tetapi harus diajukan pengesahan guna memperoleh status badan hukum. Akibat hukum PT yang memiliki besaran modal dasar kurang dari ketentuan dalam UUPT. PT tidak memiliki status badan hukum karena setelah akta pendirian atau Anggaran Dasar PT selesai dibuat maka untuk memperoleh status badan hukum haruslah mengajukan permohonan ke Menteri Hukum dan Hak Asasi Manusia untuk memperoleh pengesahan. Melalui penelitian ini diharapkan kepada pemerintah segera melakukan pengkajian dan evaluasi pada peraturan perundang-undangan terutama pada bidang hukum perusahaan.
\end{abstract}

Kata Kunci: Minimal Modal Dasar; Perseroan Terbatas; Anggaran Dasar

\begin{abstract}
In Article 33 of the Company Law, regarding the regulation of the capital of a PT, it is determined that at least $25 \%$ of the authorized capital in Article 32 of the Company Law must be issued and fully paid. This study aims to determine the regulation of the minimum amount of authorized capital at the establishment of a PT and to find out the consequences of the legal position of a PT established with an amount of authorized capital that is less than the provisions in the Company Law. This study uses a normative legal research method with a statutory approach and legal concepts. The results of the study show that the arrangement of the authorized capital of PT in PP Number 29 of 2019 is contrary to Article 32 paragraph (1). Establishing a PT to obtain a legal entity is not enough by making the Articles of Association of a PT, but it must be submitted for approval to obtain legal entity status. The legal consequence is that PT which has an authorized capital amount is less than the provisions in the Company Law. PT does not have legal entity status because after the deed of establishment or the Articles of Association of the PT has been completed, to obtain legal entity status one must submit an application to the Minister of Law and Human Rights for approval. Through this research, it is hoped that the government will immediately conduct an assessment and evaluation of laws and regulations, especially in the field of corporate law.
\end{abstract}

Keywords: Basic Capital; Limited Liability Company; Articles of Association

\section{PENDAHULUAN}

Perseroan Terbatas (selanjutnya disebut PT) merupakan salah satu badan usaha yang mulai digemari oleh masyarakat. Keberadaan PT di Indonesia diatur dalam insturmen hukum yang bersifat khusus dan meyeluruh yaitu di dalamUndang-Undang Republik Indonesia nomor 40 tahun 2007 tentang Perseroan Terbatas (selanjutnya disebut UUPT)sebagai cerminan dari bunyi Pasal 33 ayat (1) sampai ayat (4) Undang-Undang Dasar Negara Republik Indonesia tahun 1945 (selanjutnya disebut UUD 1945).

Modal atau saham adalah suatu kategori kebendaan yang juga sebagai bagian penting dalam suatu pendirian PT (Hasbullah, 2002). Sifat kebendaan saham merupakan cerminan dari pengaturan pada Pasal 509 sampai dengan Pasal 518 Burgerlijk Wetboek atau Kitab Undang-Undang Hukum Perdata 
(selanjutnya disebut BW) (Subekti, 2003). Mengenai modal dasar pada PT, Pasal 32 UUPT menyebutkan bahwa:

(1) Modal dasar Perseroan paling sedikit Rp. 50.000.000,00 (lima puluh juta rupiah)

(2) Undang-Undang yang mengatur kegiatan usaha tertentu dapat menentukan jumlah minimum modal Perseroan yang lebih besar daripada ketentuan modal dasar sebagaimana dimaksud pada ayat (1).

(3) Perubahan besarnya modal dasar sebagaimana dimaksud pada ayat (1), ditetapkan dengan Peraturan Pemerintah.

Berdasarkan bunyi Pasal 32 ayat (1) UUPT tersebut di atas, dalam mendirikan suatu PT haruslah memiliki modal dasar paling sedikit sebesar Rp 50.000.000,00 (lima puluh juta rupiah). Seiring dengan bunyi pengaturan mengenai perubahan modal dasar PT yang tercantum pada Pasal 32 ayat (1) UUPT, modal dasar PT yang pada pengaturan awalnya adalah ditetapkan sejumlahRP.50.000.000,- (lima puluh juta rupiah)ternyata telah mengalami perkembangan dan perubahan pada saat ini yang ditentukan dengan berdasar kepada suatu peraturan pemerintah yaitu Peraturan Pemerintah Republik Indonesia nomor 29 tahun 2016 tentang Perubahan Modal Dasar Perseroan Terbatas (selanjutnya disebut PP 29/2016). Pasal 1 PP 29/2016 mengenai besaran minimum modal dasar sebuah PT, menentukan bahwa:

(1) Perseroan Terbatas wajib memiliki modal dasar perseroan.

(2) Modal dasar Perseroan Terbatas harus dituangkan dalam anggaran dasar yang dimuat dalam akta pendirian Perseroan Terbatas.

(3) Besaran modal dasar Perseroan Terbatas sebagaimana dimaksud pada ayat (1) ditentukan berdasarkan kesepakatan para pendiri Perseroan Terbatas.

Berdasarkan pada bunyi pengaturan pada Pasal 1 ayat (3) PP 29/2016, mengenai jumlah total modal inti (dasar)pendirian PT adalah bebas denganpersyaratan bahwa jumlahnya harus ditentukan dan dituangkan ke dalam Anggaran Dasar PT yang hendak didirikan. Jadi syarat pokoknya adalah berdasarkan pada kesepakatan dari seluruh pendiri PT. Berdasarkan konflik norma yang telah dipaparkan maka penelitian ini bertujuan untuk menganalisis dan memahami tentang dasar hukum pengaturan jumlah minimal modal dasar pada pendirian PT dan mengetahui kedudukan hukum PT yang didirikan dengan jumlah modal dasar yang kurang dari ketentuan dalam UUPT.

\section{METODE PENELITIAN}

Penelitian ini menggunakan penelitian hukum normatif dengan menggunakan pendekatan perundangundangan dan pendekatan konseptual (Mahmud, 2009). Selanjutnya, penelitian dilakukan secara sistematik dan terperinci guna membahas seluruh permasalahan dengan menggunakan beberapa pedoman yang diperoleh dari kepustakaan dan peraturan perundang-undangan dan teori-teori hukum (Amiruddin and Asikin 2012:166). Adapun bahan hukum yang digunakan yaitu:

1. Bahan Hukum Primer

1) Undang-Undang Dasar Negara Kesatuan Republik Indonesia tahun 1945;

2) Undang-undang Republik Indonesia nomor 40 tahun 2007 tentang Perseroan Terbatas;

3) Peraturan Pemerintah Republik Indonesia nomor 29 tahun 2016 tentang Perubahan Modal Dasar Perseroan Terbatas

2. Bahan Hukum Sekunder, seperti buku-buku atau literatur, hasil-hasil karya dari kalangan hukum serta artikel-artikel yang diperoleh melalui media cetak maupun media elektronik yang terkait dengan permasalahan yang diangkat dalam penelitian ini.

Pengumpulan bahan hukum dilakukan dengan cara studi kepustakaan dan studi dokumentasi yang difokuskan terhadap bahan-bahan hukum primer maupun bahan-bahan hukum sekunder yang berkaitan dengan modal dasar PT. Analisa bahan hukum dilakukan setelah seluruh bahan hukum yang diperlukan terkumpul, yang kemudian dianalisis secara kualitatif.

\section{HASIL DAN PEMBAHASAN}

\section{Pengaturan Jumlah Minimal Modal Dasar pada Pendirian PT}

Menurut UUPT, di dalam pendirian suatu PT dikenal istilah-istilah seperti adanya berbagai jenis modal dari modal inti atau dasar, kemudian modal diam (mengendap), dan juga modal yang disetorkan. Modal inti merupakan seluruh nilai atau jumlah daripada total keseluruhan saham dalam pendirian sebuah perusahaan (PT) yang berdasarkan UUPT haruslah ditulis dan disebutkan di dalam Anggaran Dasar PT. 
Modal inti dalam sebuah perusahaan yang berupa PT yang telah menjadi harta kekayaan yang terpisah dari pendirinya akan menjadi bentuk modal yang selanjutnya dapat diterbitkan PT untuk diperjualbelikan. Terkait hal tersebut, seluruh hal yang berkaitan mengenai penyetoran, pembelian, penjualan dan jumlah dari modal inti sebuah perusahaan yang berbentuk PT haruslah ditulis dan disebutkan di dalam Anggaran Dasar beserta perubahan-perubahannya. Keseluruhan Jumlah nilai modal yang telah disebut dan ditentukan dalam Anggaran Dasar merupakan suatu "nilai nominal yang murni" (Harahap, 2016).

Modal inti dari sebuah perusahaan yang berbentuk PT adalah gambaran dari keseluruhan syarat pemenuhan dari jumlah modal yang harus dimiliki PT sebagaimana yang telah diatur dalam peraturan perundang-undangan. Terkait hal tersebut, mengenai jumlah dari syarat minimal jumlah modal inti atau dasar di dalam suatu PT dapat ditentukan lain jumlahnya berdasarkan peraturan perundang-undangan lain sebagaimana yang dikaitkan dengan bidang usaha dari lingkup kegiatan PT yang hendak didirikan, terutama sebagaimana yang diatur di dalam peraturan perundang-undangan di bidang penanaman modal, izin usaha, perizinan, dan lainnya sebagaimana yang telah diisyaratkan dalam Pasal 31 UUPT. Lebih lanjut, dilihat dari pengaturan UUPT mengenai modal dasar atau modal inti sebuah perusahaan yang berbentuk PT haruslah minimal berjumlah RP.50.000.000,- (lima puluh juta rupiah), namun akan tetapi kembali lagi seperti yang telah disebutkan sebelumnya bahwa selain pengaturan di dalam UUPT, akan ada banyak peraturan perundang-undangan lain yang mengatur dan menentukan secara spesifik mengenai syarat minimal jumlah modal dasar atau modal inti pendirian sebuah PT. Namun mengenai penentuan dari perubahan syarat minimal jumlah modal inti pendirian PT haruslah diberikan pengaturannya di dalam suatu Peraturan Pemerintah atau yang sederajat.

Terkait pentingnya pengaturan mengenai syarat minimal jumlah nilai modal inti atau modal dasar dalam pendirian sebuah PT, suatu aturan tidaklah boleh berlaku statis, namun juga aturan-aturan yang baru yang dimaksudkan untuk menjawab perubahan dan juga perkembangan keadaan perekonomian tidaklah diperkenankan untuk bertentangan dengan hirarki peraturan perundang-undangan yang berlaku di Indonesia yang terutama adalah bersumber pada kaidah-kaidah UUD 1945. Berdasarkan bunyi Pasal 32 UUPT, modal dasar atau modal inti dalam pendirian PT adalah juga sebagai penentuan dari jumlah maksimal dari lembaran saham yang dapat diterbitkan oleh PT itu sendiri oleh karenanya modal dasar atau modal inti PT biasanya terbagi dalam sepuluh buah nilai modal. Selain itu modal dasar atau modal inti PT adalah parameter dasar yang dijadikan penunjukan perusahaan dan penggolongannya (Sembiring, 2008).

Berdasarkan bunyi Pasal 32 ayat (1) UUPT, dalam mendirikan suatu PT haruslah dengan melakukan suatu penyetoran jumlah modal minimal senilai RP. 50.000.000,- (lima puluh juta rupiah). Namun, terkait jumlah minimal modal dasar PT tersebut, Peraturan Pemerintah Republik Indonesia nomor 29 tahun 2016 tentang Perubahan Modal Dasar Perseroan Terbatas (selanjutnya disebut PP 29 Tahun 2016). Pasal 1 PP 29 Tahun 2016 mengenai besaran minimum modal dasar sebuah PT, menentukan bahwa:

(1) Perseroan Terbatas wajib memiliki modal dasar perseroan.

(2) Modal dasar Perseroan Terbatas harus dituangkan dalam anggaran dasar yang dimuat dalam akta pendirian Perseroan Terbatas.

(3) Besaran modal dasar Perseroan Terbatas sebagaimana dimaksud pada ayat (1) ditentukan berdasarkan kesepakatan para pendiri Perseroan Terbatas.

Berdasarkan pengaturan Pasal 1 ayat (3) PP 29 Tahun 2016, besaran dari modal dasar sebuah PT adalah bebas dengan cara ditentukan dalam Anggaran Dasar PT berdasarkan kesepakatan para pendiri. Hal ini berarti ketentuan pada Pasal 1 PP 29 Tahun 2016 mengenai modal dasar minimum sebuah PT adalah bertentangan dengan pengaturan yang telah diisyaratkan pada Pasal 32 ayat (1) UUPT. Dengan kata lain, lewat aturan terbaru ini (PP 29/2016), ketentuan besaran dari minimal jumlah modal inti atau modal dasar pendirian PT yang semula ditentukan pada Pasal 32 ayat (1) UUPT sebanyak RP50.000.000,(lima puluh juta rupiah), yang berdasarkan PP 29 Tahun 2016 diubah menjadi jumlahnya tidak bersyarat namun harus disebut dan dicatat dalam Anggaran Dasar dengan disepakati oleh seluruh pendiri PT.

Alasan pemerintah membentuk PP 29 Tahun 2016 dilihat dari aturan bagian "menimbang" pada PP tersebut adalah untuk memberikan kemudahan berusaha bagi para pengusaha dalam mendirikan badan usaha PT, dan dalam rangka tersebut perlu diberikan keleluasaan untuk menentukan besaran modal dasar dalam memulai usaha. Terkait dengan aturan mengenai besaran minimal modal dasar PT, berdasarkan asas preferensi dan teori negara hukum milik Hans Kelsen diisyaratkan bahwa dalam 
pembentukan suatu aturan, tidaklah diperkenankan untuk menyimpang ataupun berlawanan dengan hirarki peraturan perundang-undangan yang berlaku.

Terkait dengan permasalahan tersebut, terdapat Asas preferensi yang merupakan salah satu asas dalam ilmu hukum administrasi negara yang digunakan untuk menentukan peraturan mana yang akan digunakan apabila terdapat dua aturan berbeda yang mengatur hal yang sama. Asas preferensi terbagi menjadi tiga, berikut penjabarannya:

1. Lex superiori derogat legi inferiori

Jenis aturan yang dibuat yang memiliki derajat atau kedudukan lebih tinggi akan tidak memberlakukan aturan yang memiliki derajat atau kedudukan yang lebih rendah dilihat berdasarkan hirarki peraturan perundang-undagan yang berlaku.

2. Lex specialis derogat legi generali

Jenis aturan yang dibuat yang pada dasarnya bersifat kaidah-kaidah khusus akan didahulukan dibanding dengan aturan yang kaidah-kaidahnya bersifat umum dilihat berdasarkan hirarki peraturan perundang-undagan yang berlaku.

3. Lex posteriori derogat legi priori

Jenis aturan yang dibuat lebih akhir atau paling mutakhirakan diberlakukan ketimbang jenis aturan sebelumnya dilihat berdasarkan hirarki peraturan perundang-undagan yang berlaku.

Teori tersebut digunakan saat terjadi pertentangan norma hukum (conflict of norms) seperti pertentangan dalam aturan mengenai besaran modal dasar dalam pendirian PT di dalam aturan UUPT dengan PP 29/2016, sebagaimana yang diisyaratkan berdasarkan asas preferensi yang telah disebutkan di atas yaitu pada bunyi asas Lex superiori derogat legi inferiori, dapat dirumuskan bahwa terkait adanya pertentangan norma tersebut maka aturan yang diahulukan atau yang berlaku adalah pengaturan di dalam UUPT sebagaimana UUPT merupakan instrumen hukum yang memiliki kedudukan atau derajat lebih tinggi dibanding Peraturan Pemerintah.

\section{Akibat Hukum PT yang Didirikan Jumlah Modal Dasar Kurang dari Ketentuan dalam UUPT}

Kaitannya dengan badan hukum, yang dimaksud dengan definisi sebuah PT haruslah merujuk kepada maksud pengaturannya yang telah disebutkan di dalam Pasal 1 UUPT yang pada intinya perusahaan yang berbentuk PT dalam peraturan perundang-undangan di Indonesia adalah digolongkan ke dalam suatu badan hukum. Sebagai konsekuensi dari dianutnya paham yang mendasari berlaku UUPT, yang menyatakan PT adalah badan hukum yang didirikan berdasarkan suatu perjanjian (Widjaya, 2000).

Dalam memperoleh legalitasnya dan terkait diakuinya sebuah PT sebagai sebuah badan hukum, maka dalam pendirian PT haruslah dilakukan pemenuhan persyaratan pendiriannya sebagaimana yang ditentukan oleh undang-undang yang di mana keabsahan atau status badan hukum didapatkan melalui pengesahan dari kementerian yang berwenang. Dalam mendirikan PT haruslah didahului dengan akta pendirian PT. Setelah akta pendirian PT selesai dibuat selanjutnya adalah mengajukan permohonan pada Menteri Hukum dan Hak Asasi Manusia untuk memperoleh pengesahan, agar PT memperoleh status Badan Hukum. Dalam akta pendirian PT pada umumnya memuat anggaran dasar, yang mengatur hal-hal antara lainnama perusahaan, tujuan perusahaan, kegiatan usaha, lokasi kantor pusat, jumlah Direksi, Komisaris, dan struktur permodalan.

Sebagaimana telah disebutkan bagian sebelumnya, pengesahan oleh kementerian terhadap status badan hukum PT diberikan setelah semua persyaratan dipenuhi. Pengesahan oleh kementerian dilakukan apabila tahapan-tahapan dalam pengajuan pengesahan badan hukum PT tersebut telah lengkap dan sesuai dengan prosedur. Adanya pengakuan terhadap status badan hukum dalam sebuah pendirian PT sangat mempengaruhi keberlangsungan hidup PT yang hendak didirikan karena sebuah PT merupakan salah satu subyek hukum yang tentunya dapat memiliki hak dan kewajibannya sendiri. Tentunya hak dan kewajiban itu diwakili oleh para pengurus PT. Adapun syarat-syarat sahnya pendirian PT di Indonesia yang diatur dalam UUPT adalah: Akta Pendirian, Pengesahan Oleh Menteri, dan Pendaftaran.

Terkait dengan adanya pengakuan terhadap status badan hukum sebuah perusahaan yang berbentuk PT, apabila PT yang didirikan tidak memperolehnya atau dengan kata lain tidak diakui sebagai sebuah badan hukum maka akan menyebabkan PT tersebut kehilangan pemenuhan segala hak dan kewajiban hukumnya. Dengan kata lain, seluruh pengurus PT dari atas sampai bawah atau bisa disebut sebagai stakeholders, akan melakukan tindakan dan juga tanggung jawab hukum secara 
bersama-sama (tanggung renteng) dalam artian dari seluruh tindakan atau tanggung jawab hukum tersebut secara hukum tidak diatasnamakan PT.

\section{SIMPULAN DAN SARAN \\ Simpulan}

Berdasarkan pembahasan di atas dapat disimpulkan bahwa pengaturan besaran minimal modal dasar PT adalah diatur dalam Undang-Undang No. 40 Tahun 2007 tentang Perseroan Terbatas dan isi PP No. 29 Tahun 2016. Di dalam Undang-Undang Republik Indonesia Nomor 12 Tahun 2011 tentang Pembentukan Peraturan Perundang-Undangan dinyatakan bahwa Peraturan Pemerintah sebagai aturan "organik" daripada Undang-Undang menurut hierarki tidak boleh tumpang tindih atau bertolak belakang dan Peraturan Pemerintah ditandatangani oleh Presiden. Pengaturan modal dasar PT pada PP 29 Tahun 2016 bertentangan dengan Pasal 32 ayat (1) UUPT. Perubahan aturan besaran modal dasar pendirian PT yang semula ditentukan pada Pasal 32 ayat (1) UUPT adalah paling sedikitRp 50.000.000,00 (lima puluh juta rupiah), menjadi diserahkan sepenuhnya kepada para pendiri PT dengan kesepakatan para pendiri PT yang dituangkan di dalam Akta Pendirian PT atau Anggaran Dasar. Asas Preferensi hukum yang berbunyi Lex Superior Derogat Legi Inferior mengisyaratkan bahwa peraturan yang lebih tinggi mengesampingkan yang lebih rendah, sehingga aturan yang digunakan adalah UUPT.

Kemudian, akibat hukum PT yang memiliki besaran modal dasar kurang dari ketentuan dalam UUPT. PT tidak memiliki status badan hukum karena setelah akta pendirian atau Anggaran DasarPT selesai dibuat maka untuk memperoleh status badan hukum haruslah mengajukan permohonan ke Menteri Hukum dan Hak Asasi Manusia untuk memperoleh pengesahan. Mendirikan PT sampai memperoleh badan hukum tidak cukup dengan cara membuat Anggaran Dasar PT saja, tetapi harus diajukan pengesahan guna memperoleh status badan hukum.

\section{Saran}

Melalui penelitian ini diiharapkan agar pemerintah segera melakukan pengkajian dan evaluasi pada peraturan perundang-undangan di Indonesia baik dari tingkat tertinggi sampai terendah agar tidak terjadi ketimpangan antara masing-masing aturan yang nantinya dapat menyebabkan kekacauan hukum terutama di bidang hukum perusahaan.

\section{DAFTAR PUSTAKA}

Amiruddin, \& Asikin, Z. (2012). Pengantar Metode Penelitian Hukum (VI). Jakarta: Raja Grafindo Persada. Harahap, M. Y. (2016). Hukum Perseroan Terbatas. Jakarta: Sinar Grafika.

Hasbullah, F. H. (2002). Hukum Kebendaan Perdata: Hak-Hak Yang Memberi Kenikmatan. Jakarta: Ind HillCompany.

Mahmud, M. P. (2009). Penelitian Hukum. Jakarta: Kencana Predia Media Grup.

Sembiring, S. (2008). Hukum Dagang. Bandung: Citra Aditya Bakti.

Subekti, R. (2003). Pokok-Pokok Hukum Perdata. Jakarta: Intermasa.

Widjaya, I. G. R. (2000). Hukum Perusahaan dan Undang-Undang dan Peraturan Pelaksanaan di Bidang Usaha. Jakarta: KBI.

Undang-Undang Dasar Negara Kesatuan Republik Indonesia 1945

Burgerlijk Wetboek atau Kitab Undang-Undang Hukum Perdata.

Wetboek van Koophandel, di Indonesia disebut dengan Kitab Undang-Undang Hukum Dagang.

Undang-Undang Republik Indonesia nomor 12 tahun 2011 tentang Perubahan atas Undang-Undang nomor 10 tahun 2004 tentang Pembentukan Peraturan Perundang-Undangan.

Undang-Undang nomor 25 tahun 2007 tentang Penanaman Modal.

Undang-Undang nomor 40 tahun 2007 tentang Perseroan Terbatas.

Peraturan Pemerintah Republik Indonesia nomor 29 tahun 2016 tentang Perubahan Modal Dasar Perseroan Terbatas. 